\title{
加速器による放射性同位体分析法の最近の進歩 ${ }^{+}$
}

\author{
中 井信之 \\ 名古屋大学理学部地球科学教室 \\ 464 名古屋市千種区不老町
}

Key Words: accelerator, isotope analysis, cosmogenic nuclide, tritium, carbon-14, beryllium-10, chlorine- 36

\section{1. はじめに}

最近, 世界のいくつかの研究グループが，加速器を 用いて, 超高感度で核種を定量することのできる ultr ${ }^{\mathrm{a}}$ sensitive single-atom detectionの新しい技術を発表し た。とくに1977年には雑誌 Science などに新しい技術 による ${ }^{14} \mathrm{C},{ }^{10} \mathrm{Be},{ }^{36} \mathrm{Cl}$ などの測定の可能性に関して論 じられだル4。この方法は，試料を ion ビームに変 え，数 $\mathrm{MeV}$ まで加速して高ェネルギーをあた方，電 磁場のふるいにかけて検出器により望む核種を定量す るものである。

この測定原理は, 従来安定同位体比を測定するのに 用いられてきた質量分析計と似ているが，ion ビーム に $\mathrm{MeV}$ の高エネルギーをあた光，さらに ionization detector を用いるところに大きな相違がある。ionの 検出に ionization detector を用いて高エネルギー粒子 の動的特性により，妨害 ion からの識別が可能になり， また加速器で高エネルギーを与えることにより同質量 をもつ分子イオンの妨害をとりのぞくことができる。 この新技術開発によって単原子の識別だけでなく原子 番号の識別が可能になった。したがって, 極微量の核 種も同質量をむつ分子イオンや同重体 (isobar) の妨害 なく正確に定量できるといらのである。たとえば，年 代測定に用いられる天然物の ${ }^{14} \mathrm{C}$ の定量を質量分析計 でおこならには，空気成分である ${ }^{14} \mathrm{~N}$ のバックグラウ ンドが大きいため不可能とされていたが，新技術の開 発によって, ${ }^{14} \mathrm{~N}$ と ${ }^{14} \mathrm{C}$ は明確に識別され ${ }^{14} \mathrm{C}$ の定量 が容易になったのである。

このよらに書くと, 地球科学の分野にいる筆者も同 様であるが，読者の皆さんにはこの原理自身が新しい

† Progress on Direct Detection of Radioisotopes with Accelerators. Nobuyuki NAKAI: Department of Earth Sciences, Nagoya University, Furo-cho, Chikusa-ku, Nagoya 464.
ものであるかの印象をあた兊るであろう。しかし，核 物理関係の研究にとっては, 決して耳新しいものでは ない。すでに1939年には, Alvarez や Cornog たちは, トリチウムと ${ }^{3} \mathrm{He}$ の同重体識別のために cyclotronk よるこの技術を用いている。ただいえることは，この 方面の技術の進歩により，1977年以降種々の研究分野 に同位体測定法として使用できる装置が開発され，わ れわれ素人にもこの方法が使えるようになってきたの である。

\section{2. 加速器による同位体分析装置の出現}

第二次世界大戦以来, 核反応実験にともない急速に 進歩した技術が，この極微量同位体測定技術の分野に も大きく寄与する時代がやってきた。その一つが, 質量 分析器と同じく mass separation method による ionの 直接計測である。近年 California 大字 Lawrence Berkeley Laboratory の Muller (1977) ${ }^{1)}$ と Rochester グ ループの Bennettら (1977) ${ }^{3)}$, Purserら (1977) ${ }^{4)}$ は, 初めて加速器の技術を天然の ${ }^{14} \mathrm{C}$ およびその他の放射 性同位体の直接計測に応用することを提案した。ここ で，放射能計測にたよっていた極微量放射性同位体の 新しい画期的な測定法が生まれた。さらにこの技術は， 1977年の発表以来 $1 \sim 2$ 年の間に急速な進歩を示し た。Nelson(1977) ${ }^{2)}$ は 7 MVの Tandem Van de Graaff 加速器を用いて天然濃度の ${ }^{14} \mathrm{C}$ 測定を試みた。また 1977年 5 月以来, RochesterグループとよばれるRochester 大学—General Ionex 社—Toronto 大学(RIT) の研究グループは, $8 \mathrm{MV}$ の Van de Graaff 加速器 を用いて， ${ }^{14} \mathrm{C}^{4+を}$ 約 $40 \mathrm{MeV}$ まで加速し，また ${ }^{14} \mathrm{~N}$ と ${ }^{14} \mathrm{C}$ を識別するために, negative ion を使用するなど して，精密な天然 ${ }^{14} \mathrm{C}$ の測定を可能にする努力がはら われた。またこの研究グループは, 放射性核種 ${ }^{10} \mathrm{Be}$, ${ }^{14} \mathrm{C},{ }^{36} \mathrm{Cl}$ をそれぞれ ${ }^{9} \mathrm{Be},{ }^{12} \mathrm{C},{ }^{35} \mathrm{Cl}$ に対して $1: 10^{15}$ たはそれ以下のレベルで検出する方向に研究を進め 
た。そして，RIT 研究者グループは1978年に, ${ }^{14} \mathrm{C}$ 年 代測定には炭素として数 $\mathrm{mg}$ の試料で十分であること や，10万年までの年代測定が可能であることを発表し だ。一方, California 大学の Berkeley 研究者グルー プは，同じ1978年帛に，88インチの cyclotronを用いて ${ }^{14} \mathrm{C}^{3+}$ イオンを $60 \mathrm{MeV}$ まで加速し，測定法に改良を加 爷た結果, $10 \sim 100 \mathrm{mg}$ の天然炭素試料で 4 〜 10 万年の 年代測定が可能になったことを報告している。従来の 方法では「グラムオーダ」の炭素試料を必要とし，乙 かもせいぜい $4 \sim 5$ 万年の年代が測定限界であったこ とからも, この新方法がいかに画期的なるのであるか が理解できよう。

以上述べた ${ }^{14} \mathrm{C}$ 以外飞 ${ }^{10} \mathrm{Be}$ に関しては, Berkeley 研究者グループの Muller(1977) ${ }^{1)}$ やランスのGrenoble の cyclotron を用いた Raisbeck $(1978)^{n), 8)}$ がその 測定の可能性を報告している。また， T(トリチウム) (Muller, 1977) ${ }^{1)}$ の測定も可能で ${ }^{36} \mathrm{Cl},{ }^{129} \mathrm{I},{ }^{26} \mathrm{Al},{ }^{58} \mathrm{Mn}$ についてもその可能性がでてきた9。

1978年 4 月20 21日には, ニューヨーク州のRochester 大学で “Radiocarbon Dating with Accelerators"

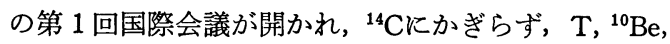
${ }^{36} \mathrm{Cl}$ の測定に関する技術の進歩とその将来，さらにそ の応用に関して議論された。そして,この会合には米, 英, 仏, 西独, スウェーデン, オランダ, カナダの各 国から約 100 人の物理学, 化学, 地質学, 地理学, 気 候学, 人類学等の研究者が集まり,28の講演がおこな われだ8。

このよらに, 新技術は極微量同位体, とくに放射性同 位体の測定に大きな革命をもたらしたといえよう ${ }^{100}$ 。 名古屋大学では, RIT 研究者グループの一人であり, General Ionex 社でこの装置 $\left({ }^{14} \mathrm{C}\right.$ 測定)の製品化に成功 した Purser 博士を招き，1978 年 9 月 5 日アイントー プ総合センターにおいて “Ultrasensitive Isotope Analysis, Including Dating, with the Rochester Tandem"

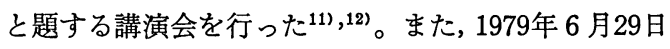
には同博士がふたたび来日し,「理工学に拈ける同位元 素研究発表会」に扔いて, “Direct Detection of Radioactive Nuclei Using Tandem Electrostatic Accelerators” と題する特別講演があり，多数の研究者の興味 をひいたのである ${ }^{13)}$ 。

\section{3. 放射性炭素 $\left({ }^{14} \mathrm{C}\right)$}

加速器による新測定装置が初めて製品化されたのは ${ }^{14} \mathrm{C}$ 測定用で，その第 1 号器が Arizona大学で本年10月 から組立がはじめられた。また，ついで Oxford 大学 にも設置がきまったといらことである。したがって， 他の同位体にくらべて， ${ }^{14} \mathrm{C}$ 測定に関する資料が多い ので, この方法の有用性を ${ }^{14} \mathrm{C}$ の場合を例にのべるこ とにする。

$3 \cdot 1$ 加速器による Direct Detection の有用性 ${ }^{14} \mathrm{C}$ (半減期 $=5,730$ 年) に関しては, 天然物を対象と する場合, 最も興味の集中するのは年代測定への応用 であろう。しかし，天然物の ${ }^{14} \mathrm{C}$ の存在比は非常に小 さく，たとえば大気中で宇宙線により核反応でつくら れた ${ }^{14} \mathrm{C}$ を含む現在の大気 $\mathrm{CO}_{2}$ と平衡にある有機体 の場合, 同位体の存在比は,

${ }^{12} \mathrm{C}:{ }^{13} \mathrm{C}:{ }^{14} \mathrm{C}=0.99: 0.01: 1.4 \times 10^{-12}$ であり，57,000年前の古い有機体では ${ }^{14} \mathrm{C}$ はさらに少 なくなり，

${ }^{12} \mathrm{C}:{ }^{13} \mathrm{C}:{ }^{14} \mathrm{C}=0.99: 0.01: 1.4 \times 10^{-15}$ である。

従来は, この微量の ${ }^{14} \mathrm{C}$ の定量は, その放射崩壊に ともなら $\beta$ 線の計測にたよってきた。天然物の ${ }^{14} \mathrm{C} の$ 研究は, 1946年 Libby一派 ${ }^{14)}$ にっってはじめられ, 現 在はすでに世界で 100 以上の研究施設で研究されてい る。これらの研究施設では主として,

表 $1{ }^{14} \mathrm{C}$ 年代測定における加速器法と $\beta$ 線計測法の比較 (Purser, 1979)

\begin{tabular}{|c|c|c|c|c|c|c|c|}
\hline 試料の年齢 & \multicolumn{2}{|l|}{ 現 } & 代 & \multicolumn{2}{|c|}{6 万 年 } & \multicolumn{2}{|c|}{10 万 年 } \\
\hline 定 法 & 放 射 能 & 加 & 器 & 放 射 能 & 加 速 器 & 放射能 & 加 速 器 \\
\hline 試料使 用 量 & $1 \mathrm{~g}$ & $<1 \mathrm{mg}$ & $20 \mathrm{mg}$ & $7 \mathrm{~g}$ & $2 \sim 5 \mathrm{mg}$ & & $120 \mathrm{mg}$ \\
\hline カウント数 & $13.7 \mathrm{c} / \mathrm{m}$ & & $\mathrm{c} / \mathrm{m}$ & $0.058 \mathrm{c} / \mathrm{m}$ & $0.7 \mathrm{c} / \mathrm{m}$ & & $0.24 \mathrm{c} / \mathrm{h}$ \\
\hline バックグラウンド & $1.6 \mathrm{c} / \mathrm{m}$ & $2 \sim 3$ & /day & $1.6 \mathrm{c} / \mathrm{m}$ & $2 \sim 3 \mathrm{c} /$ day & 不 & $2 \sim 3 \mathrm{c} /$ day \\
\hline 誤 & ～50年 & ～25年 & $0.1 \%$ & $\sim 1,800$ 年 & ～500年 & 能 & $\sim 2,500$ 年 \\
\hline 測 定 所 要 時間 & 12時間 & 15 分 & 10～20時間 & 4 日 & 2 時間 & & 1 日 \\
\hline
\end{tabular}


$\mathrm{CO}_{2}$-prorortional counter, liquid scintillation counter で測定している。しかし， ${ }^{14} \mathrm{C}$ の特別な濃縮をおこな わないかぎり，測定できる年代のはんいは 5 万年以下 である ${ }^{15), 16) 。 こ の ~} \beta$ 線計測による場合に,

(1)宇宙線によるバックグラウンドに対するシールデ ヘング

(2)試料を多量に必要とする

などの問題をかかえている。たとえば, Washington 大 学の Quaternary Research Center では Stuiver 博士 が地下 $10 \mathrm{~m}$ に proportional counter を設置し，さらに $30 \mathrm{~cm}$ の厚さの鉛のシールドを用いてバックグラウン ドを必要なレベルまで少なくしている。そして，この 場合でも， $5 \sim 6$ 万年の古い試料では，その測定に最 低 $7 \mathrm{~g}$ の炭素を必要とし， $\mathrm{CO}_{2}$ を3.1気圧で proportional counter をみたさねばならないといらことである。

このようにして，手のこんだ設備でバッククラウン ドを減らしたとしても，なお多量の試料が要求される。 そこで, 多量に入手または前処理不可能な地質学的試 料や, 貴重な考古学的試料，あるいは破壊することの 許されない微量の試料を測定でき，しかも高精度で古 い年代にわたる測定のできることが強く要請されてき た。また，年代測定やトレーサー実験の測定にかぎら ず，原水爆実験，原子力発電，核融合実験にともなら 放射性同位体による環境污染のモニタリンクや污染物 質の自然界への蓄積に関する基礎研究，さらに天然に おける放射性物質のバックグラウンドの把握のために も，新技術の開発がまたれたわけである。

そこで, 従来のような長い半隇期をもって崩壊する $\beta$ 粒子のカウンティングでなく,安定同位体比を質量分 析計で測定するのと同様に, ${ }^{14} \mathrm{C}$ 原子自身を直接計測 できたとすると、いかに能率がよいかを考えてみよう。 つまり, これが加速器を用いる方法開発の発端になっ たのである。まず，現代の植物では前にも述べたよう に, ${ }^{14} \mathrm{C} /{ }^{12} \mathrm{C}$ (原子比) は $1.2 \times 10^{-12} て ゙$ ，その炭素 $1 \mathrm{mg}$ 中に含まれる ${ }^{14} \mathrm{C}$ 原子の数は，

${ }^{14} \mathrm{C}=6 \times 10^{7}$ atoms $/ \mathrm{mg}$ of $\mathrm{C}$

であり， ${ }^{14} \mathrm{C}$ 原子の direct detection がたとえ測定効 率は100\%でないにしても, わずか $1 \mathrm{mg}$ の炭素試料で ばく大な数の ${ }^{14} \mathrm{C}$ を計測することになる。これに対し て, 5,730 年の半減期で崩壊する ${ }^{14} \mathrm{C}$ から放出される $\beta$ 粒子の数は ${ }^{14} \mathrm{C}$ の壊变定数を $1.4 \times 10^{-8} / \mathrm{h}$ とする と,

$$
\begin{aligned}
{ }^{14} \mathrm{C}(1 \mathrm{mg} & \text { の炭素試料中の) の 壊変率 } \\
& \doteqdot 8 \times 10^{-1} / \mathrm{h}
\end{aligned}
$$

となりたとえカウント効率が100\%であるにしても，
現代の植物で 1 時間に 1 カウント以下にすぎない。こ れらの数字をみても, direct detectionは析ちがいに効 率のよいことがわかる。それでは，10万年も古い炭素 試料についてみてみよう。その $1 \mathrm{mg}$ 炭素試料中には ${ }^{14} \mathrm{C}$ がまだ,

$$
{ }^{14} \mathrm{C}=335 \text { atoms } / \mathrm{mg} \text { of } \mathrm{C}
$$

残っている。るし direct detection が効率 100\% で可 能ならば，たとえ 10 万年の古い試料からも数百の ${ }^{14} \mathrm{C}$ を計測することになるのある。

\section{$3 \cdot 2$ 加速器による測定法}

前項にのべたことから， direct method がいかに有 効であるかわかっていただけたと思う。この direct method の最初の実用化への試みは, New York 州立 大学の Anbar 教授一派 $\left(1974^{17)}, 1975^{18)}, 1976^{19)}\right)$ に よって質量分析学会で発表された。かれらは，質量数 29 の ${ }^{14} \mathrm{C}^{15} \mathrm{~N}^{-}$の分子イオンを用いたが，同じ質量をも つ他の分子イオン $\left({ }^{12} \mathrm{C}_{2} \mathrm{H}_{5}{ }^{-},{ }^{12} \mathrm{C}^{16} \mathrm{OH}^{-},{ }^{28} \mathrm{SiH}^{-}\right)$，原 子イオン ${ }^{29} \mathrm{Si}^{-}$などの妨害が大きく実用化されなかっ た。しかし, この研究が基礎知識を与兄, 研究の引き がねになったのである。その後,この ${ }^{14} \mathrm{C}$ の測定に取

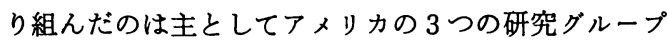
で，その方法を大別すると二つになる。その一つは Lawrence Berkeley 研究者グループによる 88 インチ cyclotron を用いたもの (Muller $\left.{ }^{1,6)}\right)$, 他の一つは, RIT 研究者グループ, McMaster 大学と Simon Fraser 大 学研究者グループが独立に Tandem Van de Graaff加速 器を用いたもの(Bennett ら ${ }^{3) ~ 5)}$, Nelson ら²) である。

この方法の原理を現在製品化された General Ionex 社の Tandem Van de Graaff を用いたものでみるこ とにする。前にものべたように，まず単原子イオンに 高エネルギー $(\mathrm{MeV})$ をあたえ，電磁場を通して質量 分析と同様に ${ }^{14} \mathrm{C}$ イオンを分離して nuclear detector により直接計測するのである。この mass separation method を天然物の ${ }^{14} \mathrm{C}$ 測定に適用するにあたっての 問題点は,

(1) ${ }^{14} \mathrm{C}$ が他の炭素同位体 $\left({ }^{12} \mathrm{C},{ }^{13} \mathrm{C}\right)$ に比べ極端に量 が少ない。

(2) ${ }^{14} \mathrm{C}$ と同じ質量をもつ分子イオン，原子イオン を取り除くか, 識別検出しなければならない。 ${ }^{14} \mathrm{C}$ の場合は空気成分の ${ }^{14} \mathrm{~N}$ がいちばん問題になる。

測定装置の構成の概略を図 1 に示した。(1)の問題に 関しては, ${ }^{14} \mathrm{C}$ の単原子イオンは高感度質量分析器に よって ${ }^{12} \mathrm{C}$ おび ${ }^{13} \mathrm{C}$ の単原子イオンから完全に分離 ができる。これも炭素がすべて単原子イオンの場合で 
Tandem Van de Graaff 加速器
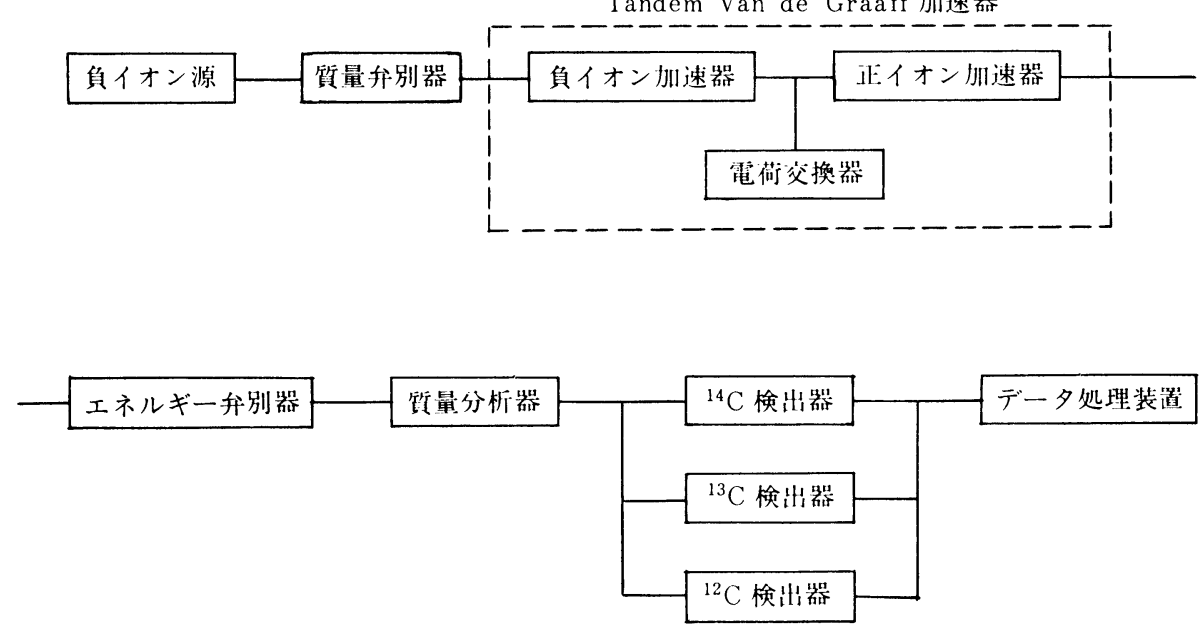

図 1 General Ionex 社製の ${ }^{14} \mathrm{C}$ 測定装置の構成

あって, 分子イオンを作ると話は変わってくる。(2)の

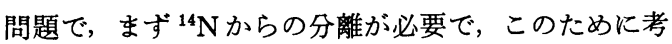
え出されたのが negative ion technique である20)。こ の negative ion technique を用いて ${ }^{14} \mathrm{~N}$ イオンをのぞ き, さらにTandem Van de Graaff 加速器を用いて効 率よく加速する方法が現在では最も有効とされてい る。

まず, ion source で試料(固体または気体)を $20 \mathrm{keV}$ の Cs 正イオンで照射して ${ }^{20)}$ ，炭素の負 ion $\mathrm{C}^{-}$として スパッターさせる。この場合，バックグラウンドや試 料中の窒素も $\mathrm{N}^{-}$ion になるが, $\mathrm{N}^{-}$ion は不安定で, ほとんどがイオンでなくなってしまう。このようにし て，注とんど窒素は電荷を失うため，次段階の質量弁 別器や加速器を通過するさい, むはや $\mathrm{C}^{-}$とは行動を ともにすることができなくなる。この最初の ion 化段 階では ${ }^{14} \mathrm{C}^{-}$以外に質量数 14 の負イオン粒子として ${ }^{13} \mathrm{CH}^{-},{ }^{12} \mathrm{CH}_{2}{ }^{-}, 2\left\{{ }^{7} \mathrm{Li}^{-}\right\}$も生まれる。ついで, 質量 弁別器 (magnetic momentum selector) を通して, 質量 数 $12,13,14$ の負イオン粒子のみを加速器に導入す る。ターミナル電圧 2〜 $7 \mathrm{MV}$ の Van de Graaff 加速 器で選ばれた質量数14粒子は加速される。途中で電荷 交換がおこなわれ，最終的には正イオンとなる。また， この加速段階で分子状イオンである ${ }^{13} \mathrm{CH}^{-},{ }^{12} \mathrm{CH}_{2}{ }^{-}$は stripping process を通して, 最終的にすべて ${ }^{13} \mathrm{C}^{4+},{ }^{12} \mathrm{C}^{4+}$ となる。この高エネルギーを与えられた正イオン粒子 は，ふたたび質量分析器を通して ${ }^{14} \mathrm{C},{ }^{13} \mathrm{C},{ }^{12} \mathrm{C}$ のそれ
ぞれの正イオンビームを分離する。 ${ }^{12} \mathrm{C},{ }^{13} \mathrm{C}$ は, 従来 質量分析で用いられている Faraday cup (検出器)によ り計測するが, ${ }^{14} \mathrm{C}$ に関しては, 特殊な nuclear detector を用いる。

${ }^{14} \mathrm{C}$ の検出には，大部分の同重体である ${ }^{14} \mathrm{~N}$ は取り 除かれたとしても，微量の ${ }^{14} \mathrm{~N}$ と識別のくふらが必 要である。すなわち, nuclear detectorには気体または 固体(薄膜)がセットされており, ion がそれらを通過 するとき，つぎの二つの無関係な kinematic parameter によって，原子番号を識別して ion の数を計測する。

(1) ion 粒子の kinetic energy: $E_{T}$

（2）気体または固体(薄膜)を通過するときの ion の 進行方向のエネルギー損失率 : $d E / d x$

たとえば, nuclear detectorに $\mathrm{Al}$ ハクか $\mathrm{Au}$ ハクを 用いると， ${ }^{14} \mathrm{C}$-ion $は{ }^{14} \mathrm{~N}$-ion よりもエネルギー損失 が少なく，ハクを通過する。また Muller たちはハク の代わりに Xe ガスを用い, ${ }^{14} \mathrm{C}$-ion $は{ }^{14} \mathrm{~N}$-ion の 1.3 倍の飛程 (距離) を有することを利用して, ${ }^{14} \mathrm{~N}$ -ion の存在を $10^{-14}$ 以下に減少させることに成功して いる。このようにして, ion フィルターにかけること により妨害イオンをのぞくことができる。この検出器 でえられるパターンを図 $2 \mathrm{~A} に$ 示した。加速イオンの kinetic energy $E_{T}$ と $d E / d x$ のパラメータにより, 質量数だけでなく原子番号が識別できることがわか る。また図 3 に模式的に示したように ion の計測数は $Z$ 軸方向に示すことができるのである。さらに，実際 


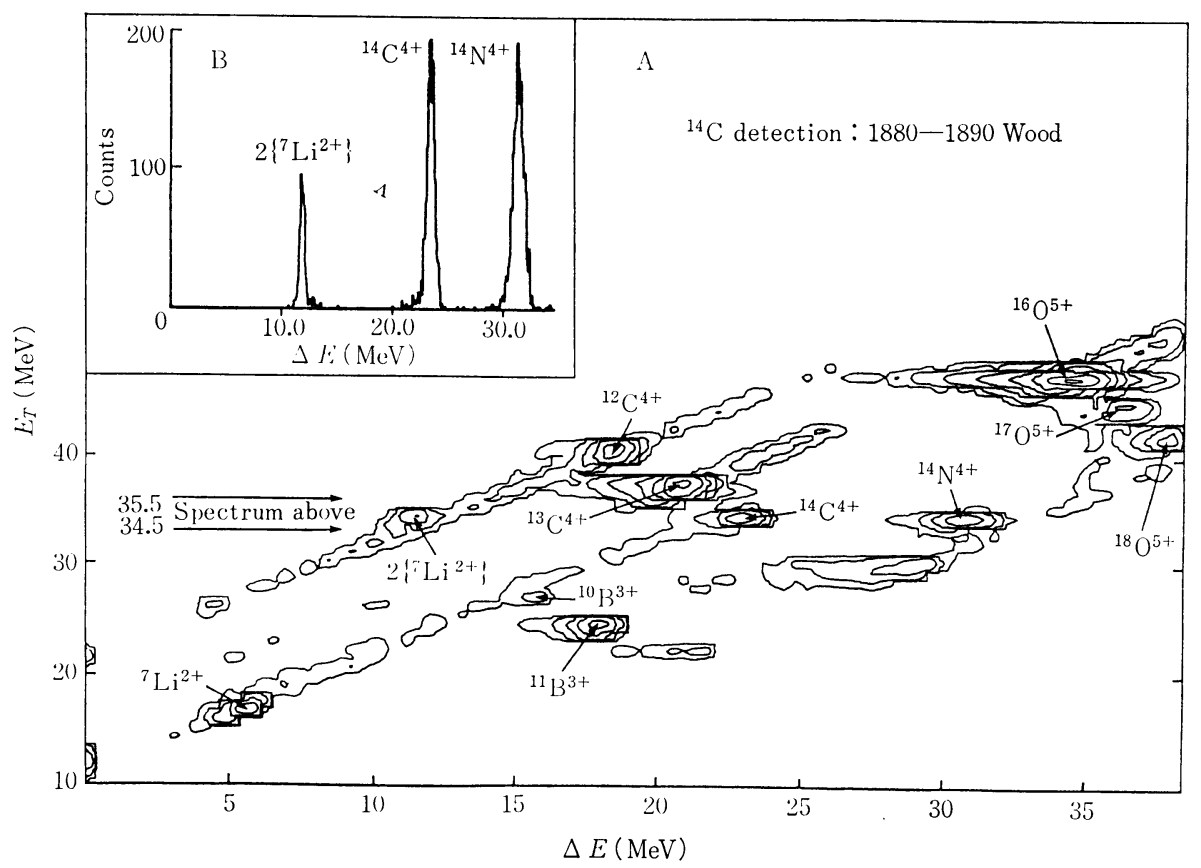

図 2 加速器による ion の識別 (Nelson, et al., 1977)

A : ion の total energy $\left(E_{T}\right)$ と energy loss $(\Delta E)$ の関係。Z 軸方向は ion の計測数。 B : total energy $34.5 \sim 35.5 \mathrm{MeV}$ の範囲での $\Delta E$ の相違による ion の識別。

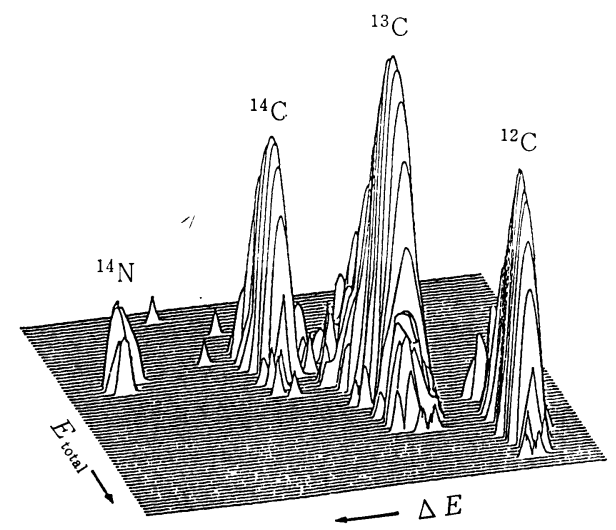

図 $3 E_{T}$ と $\Delta E$ 扎よび ion 計測数の関係を示す 立体図 (W-3703 MT. SHASTA 4590土 250 yrs. USGS)

の測定では， $E_{T}$ をある幅にしぼり計測するが,たとえ

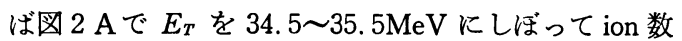
を計測すると，図 $2 \mathrm{~B}$ に示すよらに, $d E / d x$ の異な る位置にピークがみられ， ${ }^{14} \mathrm{C}$ と ${ }^{14} \mathrm{~N}$ を完全に分離す ることができる。

つぎに, 加速器で ${ }^{14} \mathrm{C}$ を測定する場合の試料の前処 理についてふれておかねばならない。それには
(1) Sputtering 法
(2) Penning 法

がある。前者は試料を固体のまま ion sourceにセット し，これにCs ion を照射する方法で，とくに前処理 の必要もなく，また一度に40試料をセットできる。後 者は, 従来の gas counter 法の場合と同じように, 前 もって試料から $\mathrm{CO}_{2}$ ガスを調製しておき，この $\mathrm{CO}_{2}$ を ion source に導入する方法である。

\section{$3 \cdot 3$ 加速器による実測の結果}

1978年になって, 加速器による測定結果が報告さ れるようになった。まず最初に，3・1 でのべた期待さ れる利点が事実であるかどらかみてみよう。Purser $(1979)^{11)}$ は㬰測結果をもとにして， $\beta$ 線計測法と Tandem 加速器による direct detection 法との比較を, 試料所要量, 計測所要時間等について報告している(表 1)。この表から，加速器法を用いることにより，ほと んど0に等しいバックグラウンドで, $\mathrm{mg}$ オーダの試 料で10万年の古い年代にまで ${ }^{14} \mathrm{C}$ 年代測定法が適用で きることがわかる。さらに测定に要する時間も析ちが いに短くてすむのである。

さらに, 地質学的, 考古学的試料についても検討が はじめられている。これらは，すでに年代がわかって いるものについて抗なわれた。まず，表 2 に，木炭 
表 2 Tandem 加速器法と $\beta$ 線計測法による地質 学的試料の ${ }^{14} \mathrm{C}$ 年代值の比較 (その 1 ) (Bennett, et al., 1978)

\begin{tabular}{l|r|r|r}
\hline \multirow{2}{*}{ 試 } & $\begin{array}{c}\text { 測定時闌 } \\
\text { (分) }\end{array}$ & \multicolumn{2}{|c}{$\mathrm{r}$-年代 (年 B.P.) } \\
\cline { 3 - 5 } & 加速器法* & $\begin{array}{c}\beta \text { 線計測 } \\
\text { 法** }\end{array}$ \\
\hline 木炭(W-3629) & 90 & 220 & 220 \\
木炭(W-3703) & 180 & 5,700 & 4,590 \\
木炭(W-3663) & 90 & 8,800 & 9,150 \\
木炭(W-2823) & 400 & 41,000 & 39,500 \\
石墨 & 65 & 48,000 & - \\
\hline
\end{tabular}

* 試料の使用量は $3.5 \sim 15 \mathrm{mg}$

** アセチレンガスとして proportional counter を用

いU.S. Geological Survey で測定

や石墨の結果をあげてみた。この結果は Bennett（19

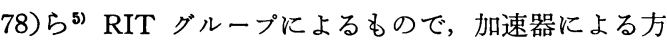
法では 3 15mg の少量試料で, 測定時間も短く, た とえ 4 万年の古い試料でも 7 時間足らずである。そし て，その測定年代は従来の方法によるものとよく一致 している。また，ごく最近のデータについても表 3 に 示した。

ここでのべた結果以外に， ${ }^{14} \mathrm{C}$ 測定に関する $\beta$ 線計 測法との詳細な比較 ${ }^{15)}$ ，さらに新しい試み ${ }^{11)}$ ，などの 報告があるが, 加速器による方法の利点をまとめると つぎのようになる。

(1) 試料の量が従来の方法の $1 / 1000$ の数 $\mathrm{mg}$ で測定 できる。

(2) 計測のバックグラウンドの心配がない。

(3) 測定に要する時間が短い。

（4）約10万年までの年代測定が可能である。

\section{4. ベリリウム $10\left({ }^{10} \mathrm{Be}\right)$}

${ }^{14} \mathrm{C}$ にくらべ ${ }^{10} \mathrm{Be}$ はその半減期の長い $\left(1.5 \times 10^{6}\right.$ 年)
ことから，さらに長い年代を知るのに有用である。す なわち, 大気中の $\mathrm{O}, \mathrm{N}$ と宇宙線の相互作用で生ずる この ${ }^{10} \mathrm{Be}$ の測定は, 海洋の循環速度や海底堆積物の堆 積速度，氷床の年代を知るだけでなく，過去百万年間 ほどの宇宙線強度の時間変動を知るのに用いられる。 このような cosmogenic ${ }^{10} \mathrm{Be}$ は微量であることと, 半 減期が長いために従来の放射能計測法では非常に困難 である。しかし，このような長寿命核種に関してはと くに加速器による direct detection が有利なのである。 そして, 深海堆積物では ${ }^{10} \mathrm{Be} /{ }^{9} \mathrm{Be}$ 比は $3 \times 10^{-8}$ ，石質隕 石では $9 \times 10^{-6}$ 等の值がえられており (Arnold, 1978) ${ }^{8)}$ また年代の古いものほどさらに比は小さくなる。

Raisbeckら (1978) ${ }^{7), 8)}$ は, Grenoble cyclotron を用 いて, ${ }^{10} \mathrm{Be}$ の測定を試みている。かれらは $\mathrm{BeO}$ をイ オン源の sputtering system にセットし, ${ }^{10} \mathrm{Be}^{2+}$ ion (粒 子）を $30 \mathrm{MeV}$ まで加速している。この ${ }^{10} \mathrm{Be} /{ }^{9} \mathrm{Be}$ 比測 定にあたっては, ${ }^{9} \mathrm{Be}$ は Faraday cup で, ${ }^{10} \mathrm{Be}$ は nuclear

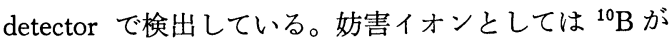
あり, ${ }^{10} \mathrm{~B}$ の存在は ${ }^{10} \mathrm{Be}$ にくらべ析ちがいに多い。こ の妨害を除くには, Muller(1977)1) の方法によってい る。すなわち, nuclear detector 中に $13.13 \mathrm{mg} / \mathrm{cm}^{2}$ の $\mathrm{Al}$ ハクをおくことにより， ${ }^{10} \mathrm{~B}$ は完全に吸収され，そ れを完全に通過する ${ }^{10} \mathrm{Be}$ のみを計測することができ る。そして，既知の ${ }^{10} \mathrm{Be} /{ }^{9} \mathrm{Be}$ 比試料 $\left(10^{-8}, 10^{-9}, 10^{-10}\right)$ について測定した結果は図 4 のごとくである。この図 から, 既知の ${ }^{10} \mathrm{Be} /{ }^{9} \mathrm{Be}$ 比と, 加速器法で測定した比 はよい一致を示すことがわかる。しかし，問題は ${ }^{10} \mathrm{Be}$ $/{ }^{9} \mathrm{Be}$ の絶対比測定だけではこのようなよい一致はみら れない。図4の測定值とされているのは，すべて比の わかった standard と交互に比を測定し，その standard の比にノーマライズしてあるのである。この standard によるノーマライズを抗こなわず絶対比を測定する

表 3 Tandem 加速器法と $\beta$ 線計測法による ${ }^{14} \mathrm{C}$ 年代の比較（その 2 ）

(RIT グループ, 1979)

\begin{tabular}{|c|c|c|c|c|c|c|}
\hline \multirow{2}{*}{ 測定年月 } & & \multirow{2}{*}{$\begin{array}{l}\text { 試料量 } \\
\text { (mg) }\end{array}$} & \multirow{2}{*}{$\begin{array}{c}\text { 測定時間 } \\
\text { (分) }\end{array}$} & \multirow{2}{*}{$\begin{array}{c}\text { 加速器による } \\
{ }^{14} \mathrm{C} /{ }^{12} \mathrm{C}\end{array}$} & \multicolumn{2}{|c|}{${ }^{14} \mathrm{C}$-年代（年B.P.） } \\
\hline & & & & & 加速器法 & $\beta$ 線計測法* \\
\hline 1978. June & 西暦1860年の木 & 1 & 162.6 & $13 \times 10^{-12}( \pm 3 \%)$ & & \\
\hline 1978. June & Shasta 山の炭化木 & 9 & 249.4 & $6.74 \times 10^{-13}( \pm 4 \%)$ & $4,640 \pm 330$ & $4,590 \pm 250$ \\
\hline 1978. June & "l & 9 & 102.5 & $6.79 \times 10^{-13}( \pm 1.1 \%)$ & $4,580 \pm 90$ & $4,590 \pm 250$ \\
\hline 1978. Aug. & $\prime \prime$ & 9 & 155.3 & $6.41 \times 10^{-13}( \pm 1.4 \%)$ & $5,030 \pm 110$ & $4,590 \pm 250$ \\
\hline 1978. Sept. & ミイラの屍衣(エジプト) & 0.9 & 117.4 & $9.23 \times 10^{-13}( \pm 2 \%)$ & $2,070 \pm 160$ & $2,050 \pm 200$ \\
\hline 1978. Mar. & 西暦1850年の木 & & 77 & $1.13 \times 10^{-12}( \pm 1.2 \%)$ & . & \\
\hline 1979. Mar. & マンモス（ロシヤ） & 0.9 & 189 & $6.98 \times 10^{-14}( \pm 7 \%)$ & $23,000 \pm 600$ & \\
\hline
\end{tabular}

* U.S. Geological Survey にて測定 


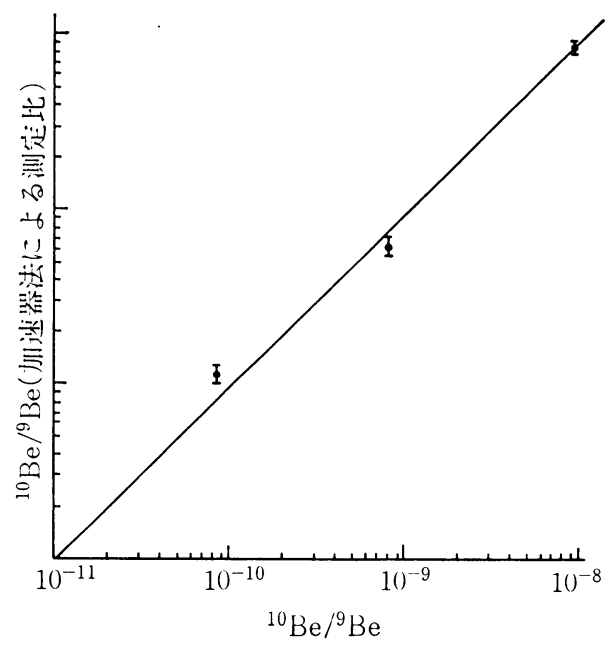

図 $4{ }^{10} \mathrm{Be} /{ }^{9} \mathrm{Be}$ 比と加速器による測定比

と，その誤差は30～50\%に達する。これは，おそらく イオン化のさい（sputtering の過程で）の同位体分別 効果によるのであろう。この研究グループはさらに測 定法に改良を加え, 感度については ${ }^{10} \mathrm{Be} /{ }^{9} \mathrm{Be}$ 比で $10^{-12}$ まで測定が可能になっている ${ }^{21}$ 。

一方, RIT研究者グループはTandem Van de Graaff で負イオンを用いて，さらに低濃度の ${ }^{10} \mathrm{Be}$ 測定に成功 している ${ }^{8), 11), 13) 。 か れ ら は ~}{ }^{10} \mathrm{Be} /{ }^{9} \mathrm{Be}$ 比が $10^{-10} \sim 10^{-13}$ の範囲で実験をおこなった。加速するイオンとして

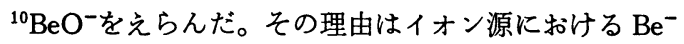
ヘのイオン化は非常に効率が悪いためである。BeO-を 作るにあたって, イオン源内の酸素分圧を $4 \times 10^{-6}$ Torr にすると ${ }^{10} \mathrm{BeO}^{-}$ion ビームは $30 \mathrm{nA}$ から $500 \mathrm{nA}$ に 増加することを見出している。つぎに検出器の段階で

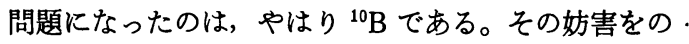
ぞくのは, ionization detector $K 13.6 \mathrm{mg} / \mathrm{cm}^{2}$ の $\mathrm{Al}$ ハクを取り付ける方法が最良とされた。そして ${ }^{10} \mathrm{Be}$ のみを計数することができる。この RIT 研究者グル 一プによる方法では, イオン化のさいの同位体効果を 最小限におさえることができた。その誤差は $2 \%$ 程度
におさえることができるので， ${ }^{10} \mathrm{Be} /{ }^{9} \mathrm{Be}$ 絶対比の測定 が可能とされている。

以上のように, ${ }^{10} \mathrm{Be} /{ }^{9} \mathrm{Be}$ 比の加速器による直接測定 は, 天然物の同位体比測定が可能の域に達したといえ よう。この加速器による天然物試料の測定はまだ数少 ないが, Raisbeck ら (1978) ${ }^{21)}$ の南極でえられた氷床 の測定例を紹介しておく。この水は東南極の Dome C で採られた $900 \mathrm{~m}$ の長さのュフで, このなかから推定 年代 (水床の堆積速度から推算)約 1,000 年および 5,000 年の 2 試料について測定している。その結果は表 4 亿 示したが, $10 l$ の水からイオン交換樹脂で Be を集 め, $\mathrm{BeO}$ をペレットにして cyclotronを用いて前述の方 法 ${ }^{7), 8)}$ で測定した $\left({ }^{10} \mathrm{Be} /{ }^{9} \mathrm{Be}\right.$ 比既知の standard の値に ノーマライズした)。感度は ${ }^{10} \mathrm{Be} /{ }^{9} \mathrm{Be}$ で $10^{-12}$ であっ た。 ${ }^{10} \mathrm{Be} /{ }^{9} \mathrm{Be}$ 比の測定結果は，約 1,000 年 B.P. の水と 約 5,000 年 B.P. の水でそれぞれ $7.6 \pm 2.5 \times 10^{-13}, 11.2$ $\pm 2.8 \times 10^{-13}$ となって扣り,これは氷堆積当時の地球 磁場強度の違いが原因していると考学られている。す なわち一般に5,000年B.P.の地球磁場の強度は， 1,000

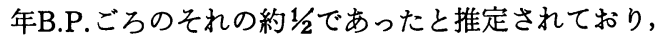
そのことと ${ }^{10} \mathrm{Be}$ 濃度はよい一致を示している。すな わち, 地球磁場により地球大気への宇宙線到達度が变 化することにより, ${ }^{10} \mathrm{Be}$ の生成量む変化するのである。 まだ測定例は少ないが，この水床の ${ }^{10} \mathrm{Be}$ の測定一つ をとってみても，過去に放射能計測で測定した McCorkell ら (1967) ${ }^{22)}$ は, $1.2 \times 10^{6} l$ と驚くべき多量の 氷を用いている。これに対し, 加速器法では $10 l$ の試 料で測定が可能なのである。このように, ${ }^{10} \mathrm{Be}$ の測定 では, 従来の方法にくらべ析ちがいに少ない試料で測 定ができるよらになったのである。そして，いままで 測定が不可能であった対象物にも測定の道が開かれた といえるであろう。

\section{5. トリチウム $(\mathbf{T})$}

トリチウムの研究にcyclotronが使われたのは，前に 述べたようにかなり古く,いまから約40年前にAlvarez

表 4 南極水床の ${ }^{10} \mathrm{Be}$ の測定

(Raisbeck, 1978)

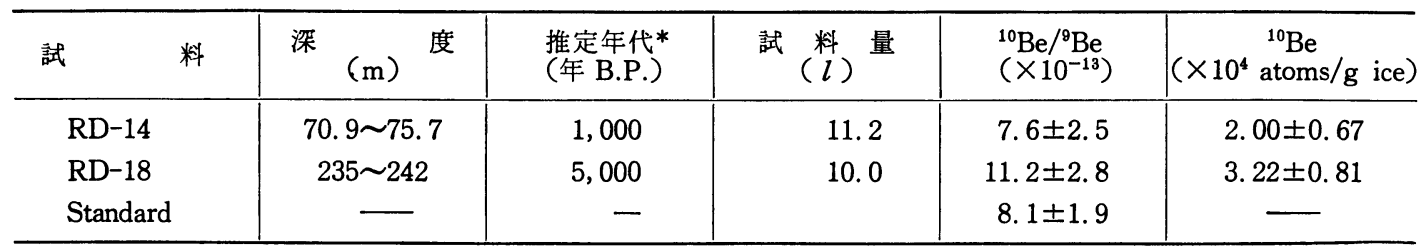

* 水床堆積速度ょりの推定值 
と Cornogにより同重体である ${ }^{3} \mathrm{He}$ との識別のためで あった。その後, この方法を天然のトリチウム定量に 適用するための努力がはらわれ，1977年に Lawrence Berkeley Laboratory の研究者グループが $2 \mathrm{MeV}$ の cyclotron で測定に成功した ${ }^{1}$ 。

このトリチウム（半減期 $=12.26$ 年)は1950年代以前 は大気中で宇宙線中の陽子または中性子と大気中の O，N.の核反応によって生成されるだけであった。と ころが, 1960年代にはいって, 水爆実験によりトリチウ ムが放出されその污染が問題にされるようになり，さ らに核融合実験にともなう将来の污染が心配されるよ らになってきた。しかし,トリチウムの場合も ${ }^{14} \mathrm{C},{ }^{10} \mathrm{Be}$ の場合と同様に, 現在の放射能計測法では多くの試料 と，長時間の前処理および計測を要するだけでなく， 天然物では測定不能のものさえある。

そこで登場したのが加速器による direct detection

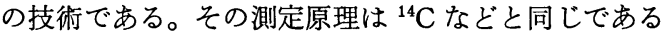
ので詳しく述べることを差しひかえる。Tandem 加速 器を用いる場合 ${ }^{11)}$ ，トリチウムの負イオンを作り，3 〜 $6 \mathrm{MeV}$ まで加速する。そして, 検出器の段階で妨害 するのは ${ }^{3} \mathrm{He}$ であるので, nuclear detector に $\mathrm{Al}$ 八 クを用いることによりそれを取り除くことができる。 すなわち，T-ion は $\mathrm{Al}$ ハクを通過しらるが， ${ }^{3} \mathrm{He}$-ion は通過しえないことを利用して識別計測することがで きる。RIT 研究者グループの研究によると, 試料を $\mathrm{H}_{2}$ ガスにして $10 \sim 20 \mathrm{~atm} . \mathrm{cm}^{3} / \mathrm{h}$ の速度でイオン源 から加速器に流して測定した場合, その tritonの計測 数は従来の $\beta$ 線計測の場合に試料水素ガス $5.6 l$ を用 いた場合と同じである。この数字からも，新技術によ る方法はいかに感度よく測定できるかが理解できよ ら。

現在の雨水にはトリチウムは 10～100TU(1 tritium unit $=1$ triton $/ 10^{18}$ hydrogen atoms)含まれている。す なわち,

$$
\mathrm{T} / \mathrm{H}=10 \sim 100 \times 10^{-18}
$$

である。このほとんど污染されていない天然水試料で も，水素ガスとして数 $10 \mathrm{cc}$ (NTP) あれば十分測定可 能であり，しかも測定時間はわずか 1 時間ですむこと になる。したがって現在の水試料ではわずか $20 〜 30$ mgで十分であることになる。 liquid scintillation counter により放射能計測をおこならとすれば，水試料の 場合少なくとも $1 \mathrm{~kg}$ 以上の試料を必要とし, これを電 解により 10〜20ml をで濃縮して，さらに長時間の放 射能計測を要することとくらべると, 加速器による direct detection 法が今後われわれの研究に大きく貢献
するであろうことが期待される。

\section{6. 放射性塩素 $\left({ }^{36} \mathrm{Cl}\right)$}

${ }^{36} \mathrm{Cl}$ の存在比の測定は地下水の年令を決めるのに有 用であと考えられる ${ }^{23)} 。{ }^{36} \mathrm{Cl}$ は大気中の ${ }^{40} \mathrm{Ar}$ と宇宙 線との相互作用で生成され，その半減期は $3.1 \times 10^{5}$ 年 である。そして大気中の ${ }^{36} \mathrm{Cl} / \mathrm{Cl}$ 比は $10^{-12} \sim 10^{-13}$ 程 度であるとされている。

加速器による測定は, 1978年に RIT 研究者グルー プによる Tandem Van de Graaff を使用したものが Purser $^{11), 13)}$, Naylor ${ }^{8)}$ により報告されている。 ${ }^{36} \mathrm{Cl}$ の測定法は基本的には ${ }^{14} \mathrm{C}$ の場合と同じである。まず かれらは試料を固体の $\mathrm{AgCl}$ または $\mathrm{NaCl}$ の形でイ オン源で $\mathrm{Cs}^{-}$-ion 照射により sputterさせ $\mathrm{Cl}^{-}$とする方 法と,試料を $\mathrm{CCl}_{4}$ の形でイオン化する方法を用いた。 つぎに問題の検出器の段階での妨害イオンについて検 討を重ねている。妨害原子イオンとしては ${ }^{36} \mathrm{Ar}$ と ${ }^{36} \mathrm{~S}$ があるが，前者は負イオンが不安定であるため，加速 される以前にイオンではなくなるし， ${ }^{36} \mathrm{~S}$ はその天然 での abundance が低いため問題はない。さらに，妨害 イオン分子については，たとえば ${ }^{18} \mathrm{O}_{2}$ などはTandem 加速器中で電荷交換の段階で取りのぞかれてしまうの でこの問題もなくなる。また微量の ${ }^{36} \mathrm{~S}$ の妨害をと りのぞくには nuclear detector でそのェネルギー損失 $d E / d x$ と全ェネルギー $E_{T}$ の 2 つのパラメータで完 全に識別することができ, ${ }^{36} \mathrm{Cl}$ のみを計測することも 可能になっている。このような検討が重ねられまた 既知の ${ }^{36} \mathrm{Cl} / \mathrm{Cl}$ 比の試料での測定がくりかえされ，さ

表 5 加速器による天然水の ${ }^{36} \mathrm{Cl} / \mathrm{Cl}$ 比実測值 (Purser ら1978) ${ }^{11,13)}$

\begin{tabular}{|c|c|c|c|c|}
\hline 試 & $\left.\begin{array}{c}\mathrm{Cl}- \\
(\mathrm{mg} / \mathrm{l})\end{array}\right)$ & $\begin{array}{l}\text { 計測 } \\
\text { 時間 } \\
(\mathrm{min})\end{array}$ & $\begin{array}{c}{ }^{36} \mathrm{Cl} / \mathrm{Cl} \\
\left(\times 10^{-15}\right)\end{array}$ & \begin{tabular}{|l} 
期待され \\
る比放射 \\
能* \\
$(\mathrm{d} / \mathrm{min}$ \\
$\cdot \mathrm{g}-\mathrm{Cl})$ \\
\end{tabular} \\
\hline \multirow{3}{*}{$\begin{array}{l}\text { 地表水 } \\
\text { Rillito River, } \\
\text { AZ. } \\
\text { San Pedro Riv- } \\
\text { er, AZ. } \\
\text { 地下水 }\end{array}$} & & & & \\
\hline & 48 & 90 & $1950 \pm 150$ & 0.145 \\
\hline & $4 \sim 12$ & 204 & $650 \pm 110$ & 0.048 \\
\hline 自噴井, $A Z$. & 8 & 68 & $400 \pm 40$ & 0.030 \\
\hline 深井戸, $\mathrm{AZ}$. & 10 & 101 & $320 \pm 50$ & 0.024 \\
\hline \multicolumn{5}{|l|}{ 湖深層水 } \\
\hline $\begin{array}{l}\text { L. Ontario, NY. } \\
(5 / 19 / 1978)\end{array}$ & 27 & 41 & $210 \pm 20$ & 0.015 \\
\hline L. Ontario, NY. & 27 & 172 & $120 \pm 20$ & 0.009 \\
\hline
\end{tabular}

* 測定された ${ }^{36} \mathrm{Cl}$ 濃度から推算された比放射能 
らに化学的な精製操作を加えることにより, 現在では ${ }^{36} \mathrm{Cl} / \mathrm{Cl}$ 比の測定限界は $3 \times 10^{-16}$ といわれている。

RIT 研究グループによる天然水中の ${ }^{36} \mathrm{Cl} / \mathrm{Cl}$ 比の実 測值 ${ }^{11}$,13)を表 5 に示した。これらの值は, 試料を $\mathrm{Ag}$ $\mathrm{Cl}$ の形で, しかもわずか 16 66mg 使用して測定し たものである。これらの結果に対する地球化学的意味 については省略するが，この表からわかるように，数 $10 \mathrm{mg}$ の少量の $\mathrm{AgCl}$ を用いて, しかも計測時間は 1 〜3時間で測定可能である。また。参考までにもし放 射能計測するとした場合の比放射能をあげておいた。 これらの試料ではその比放射能は $0.009 \sim 0.15 \mathrm{~d} / \mathrm{min}$ ・ $\mathrm{g}-\mathrm{Cl}$ と非常に微弱なあのであることが理解できよう。

\section{7. おわりに}

以上, 加速器を使用した放射性同位体の直接測定法 を, ${ }^{14} \mathrm{C}, \mathrm{T},{ }^{10} \mathrm{Be}$ 扎よび ${ }^{36} \mathrm{Cl}$ とついてその最近の進歩 のあらましを述べた。これら同位体以外にも研究が進 められて拉り，この新技術が実用化の段階にきている すの，また近い将来実用化されるであろら同位体とそ の応用を表 6 に示した。このように，放射性同位体測 定法の革命ともいうべきこの加速器による直接測定の 応用範囲は非常に広い。

最後に，強調しておきたいことは，少量の試料で短 時間に測定できることから多量の試料入手が困難な地 質学的試料や，貴重な考古学的試料あるいは破壊する ことの許されない古文化財などの年代測定に大いに貢 献するであろらけれども，放射能污染に関する測定に も大いに活躍しうることを忘れてはならないことであ る。原水爆実験, 原子力発電, 核融合実験に伴ら放射 性元素の污染モニタリングや污染物質の自然界への蓄 積に関する基礎的研究, さらに放射性物質のバックグ ラウンドの把握のためにも, 加速器による測定法の進 歩がのぞまれるのである。

\section{文献}

1) R.A. Muller: Science, 196, 489 (1977)

2) E. Nelson, et al.: ibid., 198, 507 (1977)

3) C.L. Bennett, et al.: ibid., 198, 507 (1977)

4) K.H. Purser, et al.: Review de Pysique Applique, 12, 1487 (1977)

5) C.L. Bennett, et al.: Science, 201, 345 (1978)

6) R.A. Muller, et al.: ibid., 201, 347 (1978)
表 6 加速器による測定可能な放射性同位体

\begin{tabular}{c|c|c|l}
\hline 同位体 & $\begin{array}{c}\text { 半 減 } \\
\text { (年) }\end{array}$ & $\begin{array}{c}\text { 妨害 } \\
\text { 素 }\end{array}$ & \multicolumn{1}{|c}{ 応 } \\
\hline${ }^{3} \mathrm{H}$ & 12 & ${ }^{3} \mathrm{He}$ & 地下水の流動追跡と年令 \\
\hline${ }^{10} \mathrm{Be}$ & $1.5 \times 10^{6}$ & ${ }^{10} \mathrm{~B}$ & $\begin{array}{l}\text { 年代測定海洋循環速度, 堆 } \\
\text { 磁場変, 動, 宇宙線強度の変 } \\
\text { 動 }\end{array}$ \\
\hline${ }^{14} \mathrm{C}$ & 5730 & ${ }^{14} \mathrm{~N}$ & 年代測定, その他 \\
\hline${ }^{26} \mathrm{Al}$ & $7.4 \times 10^{5}$ & ${ }^{26} \mathrm{Mg}$ & 年代測定 \\
\hline${ }^{32} \mathrm{Si}$ & 650 & ${ }^{32} \mathrm{~S}$ & 地下水の年令 \\
\hline${ }^{36} \mathrm{Cl}$ & $3.1 \times 10^{5}$ & ${ }^{36} \mathrm{~S}$ & 地下水の年令 \\
\hline${ }^{53} \mathrm{Mn}$ & $3.7 \times 10^{6}$ & ${ }^{53} \mathrm{Cr}$ & $\begin{array}{l}\text { 年代測定, 宇宙線強度の変 } \\
\text { 動 }\end{array}$ \\
\hline${ }^{129} \mathrm{I}$ & $1.7 \times 10^{7}$ & ${ }^{129} \mathrm{Xe}$ & $\begin{array}{l}\text { 年代測定, 火山活動の歴史, } \\
\text { 宇宙線強度変動 }\end{array}$ \\
\hline
\end{tabular}

7) G.M. Raisbeck, et al.: ibid., 202, 215 (1978)

8) Proceedings of the First Conference on Radiocarbon Dating with Acceleators held at University of Rochester, ed. by H.E. Gove (1978)

9) T.H. Maugh: Science, 200, 635 (1978)

10） 中井信之 : Isotope News, No. 296, 1 (1978)

11) K.H. Purser: Tracer (Nagoya Univ.), 2, 2 (1979)

12）中井信之 : ibid., 2, 18 (1979)

13） K.H. Purser, et al.: 理工学に拔ける同位元素 研究発表会, 講演要旨集, 138 (1979)

14) E.C. Anderson, et al.: Science, 105, 576(1947)

15) M. Stuiver, et al.: ibid., 200, 16 (1978)

16) P.M. Groots: ibid., 200, 11 (1978)

17) R. Schnitzer, et al.: Proc. 22nd Annual Conference, ASMS, Philadelphia, 64 (1974)

18) R. Schnitzer, et al.: Proc. 23rd Annual Conference, ASMS, Houston, 479 (1975)

19) R. Schnitzer, et al.: Proc. 24th Annual Conference, ASMS, San Diego, 361 (1976)

20) R. Middleton: Nucl. Instr. and Meth., 122, 35 (1974)

21) G.M. Raisbeck, et al.: Nature, 275, 731(1978)

22) M. McCorkell, et al.: Science, 158, 1690(1967)

23) S.N. Davis: Report on the Workshop on Dating of Old Groundwater, March, 15-18, 1978, Tucson, Arizona, ed. by S.N. Davis 